\title{
GMR
}

\section{Effect of propolis ethanol extract on myostatin gene expression and muscle morphometry of Nile tilapia in net cages}

\author{
E.L. Buck ${ }^{1}$, I.Y. Mizubuti ${ }^{2}$, A.A. Alfieri ${ }^{3}$, R.A.A. Otonel ${ }^{3}$, L.Y. Buck ${ }^{4}$, \\ F.P. Souza ${ }^{2}$, O.P. Prado-Calixto ${ }^{2}$, A.R. Poveda-Parra ${ }^{2}$, L. Alexandre Filho \\ and N.M. Lopera-Barrero ${ }^{2}$ \\ ${ }^{1}$ Unidade Industrial de Rações, Integrada Cooperativa Agroindustrial, \\ Londrina, PR, Brasil \\ ${ }^{2}$ Departamento de Zootecnia, Programa de Pós-Graduação em Ciência Animal, \\ Universidade Estadual de Londrina, Londrina, PR, Brasil \\ ${ }^{3}$ Departamento de Medicina Veterinária Preventiva, \\ Programa de Pós-Graduação em Ciência Animal, \\ Universidade Estadual de Londrina, Londrina, PR, Brasil \\ ${ }^{4}$ Faculdade de Veterinária, Universidade Filadélfia, Londrina, PR, Brasil \\ ${ }^{5}$ Universidade Estadual de Maringá, Campus Regional do Noroeste, \\ Diamante do Norte, PR, Brasil \\ Corresponding author: N.M. Lopera-Barrero \\ E-mail: nmlopera@uel.br
}

Genet. Mol. Res. 16 (1): gmr16019404

Received October 5, 2016

Accepted December 12, 2016

Published March 16, 2017

DOI http://dx.doi.org/10.4238/gmr16019404

Copyright $(2017$ The Authors. This is an open-access article distributed under the terms of the Creative Commons Attribution ShareAlike (CC BY-SA) 4.0 License.

\begin{abstract}
Propolis can be used as growth enhancer due to its antimicrobial, antioxidant, and immune-stimulant properties, but its effects on morphometry and muscle gene expression are largely unknown. The present study evaluates the influence of propolis on muscle morphometry and myostatin gene expression in Nile tilapia (Oreochromis niloticus) bred in net cages. Reversed males (GIFT strain) with an initial weight of $170 \pm 25 \mathrm{~g}$ were distributed in a $(2 \times 4)$ factorial
\end{abstract}

Genetics and Molecular Research 16 (1): gmr16019404 
scheme, with two diets (DPRO, commercial diet with $4 \%$ propolis ethanol extract and DCON, commercial diet without propolis, control) and four assessment periods (0, 35, 70, and 105 experimental days). Muscles were evaluated at each assessment period. Histomorphometric analysis classified the fiber diameters into four groups: $<20 \mathrm{~mm} ; 20$ $30 \mathrm{~mm} ; 30-50 \mathrm{~mm}$; and $>50 \mathrm{~mm}$. RT-qPCR was performed to assess myostatin gene expression. Fibers $<20 \mu \mathrm{m}$ diameter were more frequent in DPRO than in DCON at all times. Fiber percentages $>30 \mu \mathrm{m}$ (3050 and $>50 \mu \mathrm{m}$ ) at 70 days were $25.39 \%$ and $40.07 \%$ for DPRO and DCON, respectively. There was greater myostatin gene expression at 105 days, averaging 1.93 and 1.89 for DCON and DPRO, respectively, with no significant difference in any of the analyzed periods. Propolis ethanol extract did not affect the diameter of muscle fibers or the gene expression of myostatin. Future studies should describe the mechanisms of natural products' effects on muscle growth and development since these factors are highly relevant for fish production performance.

Key words: Aquaculture; Myostatin; Muscle morphometry; Propolis, Oreochromis niloticus

\section{INTRODUCTION}

The Nile tilapia (Oreochromis niloticus) is one of the most commonly bred species worldwide. Brazilian tilapia production in 2014 reached 198,000 tons, or $41 \%$ of total production of freshwater fish (Ibge, 2014). Adaptability, wide geographic distribution, and high meat quality make the species highly acceptable to consumers. In fact, it is one of the most commonly bred species in tropical regions (Castagnolli, 1992; Kubitza, 2011).

High demand for tilapia meat has intensified production, increasing efficiency and lowering costs. Production in net cages yields excellent productivity/space unit results, since the cage structure offers high water renewal rates and oxygen supply, easy hauling, and lower installation costs as compared to intensive culture systems in earth ponds (Kubitza, 2011).

In spite of its advantages, production in net cages may induce stress in fish, due to the increased animal density per cubic meter of water (Adamante et al., 2008). However, several growth enhancers have been used to improve the muscle development of the animals through better nutrients in the diet and higher yield so that the negative effects of intensive production can be eliminated. Although antibiotics, ionophores, microorganisms, and salts have been used (Fuller, 1992), their indiscriminate and inadequate employment may cause adverse effects and resistance to pathogenic organisms (Lara-Flores et al., 2003). Consequently, studies on the use of functional ingredients and feeds to provide greater feed efficiency and fish yield have increased (Nayak, 2010).

Propolis is a natural product that can be used as growth enhancer. It is a resinous, adhesive, and odorous compound collected by bees from the fissures of tree trunks, flower buds, and exudates (Bankova, 2005). More than 200 chemical compounds have been identified in propolis, including the flavonoids galangin, quercetin, pinocembrin, and kaempferol; aromatic acids and esters; aldehydes and ketones; terpenoids and phenylpropanoids (caffeic and chlorogenic acids); steroids; alcohols (cinnamic, phenethylic, prenilic, isobutenol, and

Genetics and Molecular Research 16 (1): gmr16019404 
benzylic); amino acids (arginine and proline); polysaccharides; carbohydrates; fatty acids; and small amounts of other compounds (Marcucci, 1996).

Propolis has been successfully used as a growth enhancer and immuno-modulator in several fish species (Abd-El-Rhman, 2009; Deng et al., 2011; Bae et al., 2012). Research has correlated its capacity as a growth enhancer to its antimicrobial, anti-parasitic, and immune-stimulant properties (Meurer et al., 2009; Segvic-Bubic et al., 2013; Uczay et al., 2014), although to our knowledge, no studies have investigated the effect of propolis on fish morphology and muscle gene expression.

The present study aimed to assess the effect of propolis ethanol extract on the muscle morphometry and myostatin gene expression (MSTN 1) of Nile tilapia bred in net cages.

\section{MATERIAL AND METHODS}

\section{Sampling of fish}

The methodology of the present study was approved by the Committee for Ethics in the Use of Animals of the Universidade Estadual de Londrina (CEUA UEL No. 27941.2012.79).

The assay was performed at the regional campus of the Universidade Estadual de Maringá in Diamante do Norte PR Brazil, on the Corvo river $\left(22^{\circ} 36{ }^{\prime} \mathrm{S}, 52^{\circ} 50^{\prime} \mathrm{W}\right)$, an affluent of the Paranapanema river and a tributary of the Rosana hydroelectric reservoir, within the limits of the municipalities of Diamante do Norte and Terra Rica PR Brazil.

Three hundred male reversed tilapias (Oreochromis niloticus), strain GIFT, with an initial weight of $170 \pm 25 \mathrm{~g}$ were distributed in a $(2 \times 4)$ factorial design, with two diets (DPRO, commercial diet with $4 \%$ propolis ethanol extract, and DCON, commercial diet without propolis, control) and four assessment periods $(0,35,70$, and 105 experimental days). The total assay period comprised 105 days, with additional 10 days for animal adaptation. At the start of the experiment, all fish were weighed, separated, and placed in ten net cages $\left(1 \mathrm{~m}^{3}\right.$ each $)$, at a density of 30 fish per cage. The net cages were placed in a single line, intercalating cages with DPRO fish and cages with DCON fish. Water temperature was monitored throughout the experiment at three sites within the net cage line at 09:00 and 18:00 $\mathrm{h}$ daily.

\section{Propolis extracts and diets}

The $4 \%$ alcoholic propolis extract was prepared by the Laboratory of Development and Quality Control of Phytotherapic and Apitherapic Agents of the Department of Pharmacy and Pharmacology of the Universidade Estadual de Maringá, Maringá PR Brazil, following the protocol (modified) by Franco and Bueno (1999). Experimental diets comprised commercial extruded ration with $30 \%$ crude protein in 5 -mm diameter particles (Table 1).

Composition: Corn germ meal, soybean meal, wheat meal, corn, meat flour, fish flour, viscera flour, salt and vitamin mineral premix. Vitamin and mineral mix (guarantee levels per kilo of the product): folic acid: $2 \mathrm{mg}$; pantothenic acid: $50 \mathrm{mg}$; antioxidant: $0.60 \mathrm{~g}$; biotin: 0.6 $\mathrm{mg}$; cobalt: $0.2 \mathrm{mg}$; copper: $8.0 \mathrm{mg}$; iron: $60 \mathrm{mg}$; iodine: $0.5 \mathrm{mg}$; manganese $15 \mathrm{mg}$; niacin $80 \mathrm{mg}$; selenium: $0.3 \mathrm{mg}$; vitamin A: $10.000 \mathrm{UI}$; vitamin B1: $10 \mathrm{mg}$; vitamin B12: $30 \mathrm{mcg}$; vitamin B2: $20 \mathrm{mg}$; vitamin B6: $10 \mathrm{mg}$; vitamin C: $300 \mathrm{mg}$; vitamin D3: $1.200 \mathrm{UI}$; vitamin E: $160 \mathrm{UI}$; vitamin K: 9.0mg; zinc: $80 \mathrm{mg}$. Source: manufacturer.

Ethanol extract of propolis was added to the diet by direct dispersion from a solution

Genetics and Molecular Research 16 (1): gmr16019404 


Table 1. Chemical composition of the diet.
\begin{tabular}{|c|c}
\hline Nutrients & Guarantee levels \\
\hline Humidity (max) & $130 \mathrm{~g} / \mathrm{kg}$ \\
\hline Crude protein (min) & $300 \mathrm{~g} / \mathrm{kg}$ \\
\hline Ether extract (min) & $25 \mathrm{~g} / \mathrm{kg}$ \\
\hline Fiber (max) & $65 \mathrm{~g} / \mathrm{kg}$ \\
\hline Minerals (max) & $100 \mathrm{~g} / \mathrm{kg}$ \\
\hline Phosphorus (min) & $10 \mathrm{~g} / \mathrm{kg}$ \\
\hline Calcium (max) & $25 \mathrm{~g} / \mathrm{kg}$ \\
\hline Calcium (min) & $10 \mathrm{~g} / \mathrm{kg}$ \\
\hline Vitamin C (min) & $300 \mathrm{mg} / \mathrm{kg}$ \\
\hline Chemical analysis & \\
\hline Crude protein & $31.91 \%$ \\
\hline Ether extract & $4.75 \%$ \\
\hline
\end{tabular}

composed of $250 \mathrm{~mL} 4 \%$ ethanol extract of propolis and $250 \mathrm{~mL}$ cereal alcohol. The diet was dried at room temperature to evaporate the alcohol. The diet was conditioned in the original package, kept in a dry, well-aired place, and protected from light until use.

Diets were given three times a day (morning, afternoon and evening); after weighing, amounts were adjusted according to the mean weight of fish per cage.

\section{Histological analysis}

Fifteen samples of white muscle per treatment (DPRO and DCON) at each assessment time $(0,35,70$, and 105 days) were removed from the medial section, below the dorsal fin, for the evaluation of white fibers. They were fixed in $10 \%$ buffered formaldehyde, preserved in $70 \%$ alcohol, and then dehydrated in increasing solutions of ethylic alcohol, diaphanized in xylol, and placed in paraffin. Next, $4 \mathrm{~mm}$-thick transversal sections were made and stained with eosin hematoxylin (EH); laminas were made in duplicate. The diameters of 30 transversally sectioned muscle fibers were measured for each lamina with Motic Image Plus, magnified 10x (Leica microscope, USA). Diameters of the fiber were grouped into four classes: $<20 \mathrm{~mm}$; $20-30 \mathrm{~mm} ; 30-50 \mathrm{~mm}$ and $>50 \mathrm{~mm}$. Rates were expressed as proportions of fibers in each diameter class to the total fibers for the evaluation of the relative contribution of hyperplasia and hypertrophy mechanisms.

\section{RNA extraction}

Samples were collected at 0,35 , and 105 days of breeding and eight samples $(\mathrm{N}$ $=8$ ) were used for each treatment. Muscle samples were placed in tubes with RNAlater ${ }^{\mathbb{B}}$ (Invitrogen/USA) solution and kept in a freezer at $-80^{\circ} \mathrm{C}$ until analysis.

For RNA extraction, $50 \mathrm{mg}$ of each sample was weighed. We then added $1 \mathrm{~mL}$ TRIzol (Invitrogen/USA), mixed it in a tissue homogenizer and centrifuged it at $12,000 \mathrm{rpm}$ at $4{ }^{\circ} \mathrm{C}$ for $10 \mathrm{~min}$. Samples were kept at rest for $5 \mathrm{~min}$ at room temperature $\left(26^{\circ} \mathrm{C}\right)$. Next, $200 \mu \mathrm{L}$ chloroform was added. The sample was homogenized and kept at rest for $3 \mathrm{~min}$ at room temperature, and then centrifuged at $12,000 \mathrm{rpm}$ at $4^{\circ} \mathrm{C}$ for $15 \mathrm{~min}$. 
Two phases were established. The aqueous phase was placed in a new microtube to which $500 \mu \mathrm{L}$ of $100 \%$ isopropanol was added. After $10 \mathrm{~min}$ at room temperature, it was centrifuged at $12,000 \mathrm{rpm}$ at $4^{\circ} \mathrm{C}$ for $10 \mathrm{~min}$. When RNA pellet was formed, cleaning was undertaken by adding $1 \mathrm{~mL} 75 \%$ ethanol, with homogenization and centrifugation at 7500 $\mathrm{rpm}$ at $4^{\circ} \mathrm{C}$ for $5 \mathrm{~min}$. After discarding the ethanol, the RNA pellet was dried for $10 \mathrm{~min}$ at room temperature. RNA suspension was performed in DEPC water (Invitrogen/USA) and incubation at $60^{\circ} \mathrm{C}$ for $15 \mathrm{~min}$. Total RNA was calculated by spectrophotometry. Next, $1 \mu \mathrm{g}$ RNA was placed in a tube, and $1 \mu \mathrm{L} 10 \mathrm{X}$ DNAse I Reaction Buffer, $1 \mu \mathrm{L}$ DNAse Amp Grade $(1 \mathrm{U} / \mu \mathrm{L}-\mathrm{USA})$, and DEPC water sufficient to produce a total volume of $10 \mu \mathrm{L}$ were added. The solution was kept at rest at room temperature for $15 \mathrm{~min}$; then, $1 \mu \mathrm{L} 25 \mathrm{nM}$ EDTA $(\mathrm{pH}$ 8.0) was added and the solution was incubated at $65^{\circ} \mathrm{C}$ for $10 \mathrm{~min}$ for inactivation of enzyme DNAse (Invitrogen/USA).

\section{RT-qPCR}

In order to quantitatively assess myostatin levels, reverse transcription was performed, followed by real-time polymerase chain reaction (RT-qPCR) with myostatin primers, paralog MSTN 1, and reference gene beta actin $(\beta A C T)$ (Table 2) using the GoTaq ${ }^{\circledR}$ 1-Step RT-qPCR System Kit. RNA $(5 \mu \mathrm{L}), 10 \mu \mathrm{L} 2 \mathrm{X}$ GoTaq ${ }^{\circledR}$ RT-qPCR (Invitrogen/USA) Master Mix, $2 \mu \mathrm{L} 10 \mathrm{X}$ forward primer (Invitrogen/Brazil), $2 \mu \mathrm{L}$ reverse primer (Invitrogen/Brazil), $0.4 \mu \mathrm{L}$ GoScript ${ }^{\mathbb{B}}$ RT Mix (Invitrogen/USA) for 1-Step RT-qPCR 50X, $0.3 \mu \mathrm{L}$ supplemental CXR reference, and a sufficient volume of DEPC water to produce $20 \mu \mathrm{L}$ were used for each sample (one gene at a time). Reactions were performed in duplicate for each gene using the RealTime PCR 7500 system. In the case of reverse transcription, a cycle was performed at $37^{\circ} \mathrm{C}$ for $15 \mathrm{~min}$. A cycle was performed for the inactivation of reverse transcription and activation of $\mathrm{PCR}$ at $95^{\circ} \mathrm{C}$ for 10 min in real time, followed by 40 cycles of PCR in real time with denaturation at $95^{\circ} \mathrm{C}$ for $10 \mathrm{~s}$, annealing at $60^{\circ} \mathrm{C}$ for $30 \mathrm{~s}$ and an extension at $72^{\circ} \mathrm{C}$ for $30 \mathrm{~s}$. Finally, a dissociation cycle was performed at $60^{\circ}-95^{\circ} \mathrm{C}$.

\begin{tabular}{|c|c|c|c|}
\hline Gene & Primer sequence & Size of amplification $(\mathrm{pb})$ & GenBank accession \\
\hline MSTN 1 & $5^{\prime}$ CGCAACCACGGAGACAATT $3^{\prime}$ & 58 & FJ972683 \\
\hline$\beta A C T$ & $\begin{array}{l}5^{\prime} \text { ACCTTCAACACCCCCGCCAT } 3^{\prime} \\
5^{\prime} \text { ACAGGGACAGCACAGCCTGGAT 3' }\end{array}$ & 52 & EU887951 \\
\hline
\end{tabular}

Source: Mareco (2012).

Standard dilution curves in the cDNA series (with a randomly selected sample pool) were constructed for each gene under analysis to calculate its amplification efficiency. Results from the amplification reaction produced the graph of Cts vs. $\log 10$ of the number relative to the dilution copies in the series. A linear regression was performed to determine the angular coefficient of the slope, which was used to calculate the amplification efficiency using Equation 1 from Rasmussen (2001) as follows:

$$
\text { Efficiency }=[10(-1 / \text { angular coefficient of slope })] \quad \text { (Equation 1) }
$$


Calculation of relative expression (R) of target gene was based on the efficiency of amplification (E) and PCR cycle in which an increase of fluorescence above the basal sign was detected (Ct) (Pfaffl, 2001). In the case of relative quantification, the method described by Pfaffl (2001) was employed. Relative expression was determined by Equation 2 as follows:

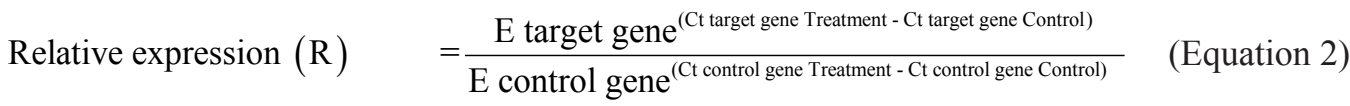

where $\mathrm{E}=$ Efficiency of primer amplification and $\mathrm{Ct}$ (threshold cycle) $=$ PCR cycle in which fluorescence above the basal signal of the equipment was detected.

\section{Statistical analysis}

Muscle fibers were grouped into classes according to their diameter: $<20 \mathrm{~mm}, 20$ $30 \mathrm{~mm} ; 30-50 \mathrm{~mm}$; and $>50 \mathrm{~mm}$. Frequency of muscle fibers (\%) was given as the number of fibers from each diameter class according to total number of fibers measured. Data on the genic expression underwent analysis of variance at the $5 \%$ significance level (significant at $\mathrm{P}$ $<0.05$ ) by the $\mathrm{R}$ statistical program.

\section{RESULTS}

\section{Water temperature}

Daily mean water temperature during the experimental months varied from $25^{\circ} \pm$ $4.6^{\circ} \mathrm{C}$ (November 2013) to $29.3^{\circ} \pm 0.3^{\circ} \mathrm{C}$ (February 2014). According to Kubitza (2011), the best temperature range for tilapia is between $26^{\circ}$ and $30^{\circ} \mathrm{C}$. Thus, the mean daily temperature was within the comfort range for tilapia during most of the experimental period.

\section{Muscle morphometry}

Fish muscle fibers registered a typical morphology compatible with the different assessment times. There was no statistical difference $(\mathrm{P}>0.05)$ in muscle growth between DPRO and DCON. However, the number of fibers of $<20 \mu \mathrm{m}$ diameter was greater in animals treated with propolis extract than in the control group for all times analyzed. It was also observed that the number of fibers increased after 35 and 70 days and decreased after 105 days. Although more fibers of $<20 \mu \mathrm{m}$ diameter were reported in DPRO after 35 and 70 days, the difference after 105 days decreased as compared to DCON. A greater number of fibers of diameter $>50 \mu \mathrm{m}$ was registered during this period, characterizing hypertrophic growth (Table 3) (Figure 1).

Analysis of the frequency of muscle fibers revealed that the percentage of fibers of up to $30 \mu \mathrm{m}$ diameter $(<20$ and $20-30 \mu \mathrm{m})$ in DPRO at 70 days reached $74.6 \%$, while the percentage of fibers of more than $30 \mu \mathrm{m}(30-50$ and $>50 \mu \mathrm{m})$ was $25.39 \%$. Similarly, DCON had $59.93 \%$ fiber diameter of up to $30 \mu \mathrm{m}$ and $40.07 \%$ of more than $30 \mu \mathrm{m}$. At 105 days, however, the frequency of muscle fibers of less than $30 \mu \mathrm{m}$ decreased for the two treatments (34.47 and 32.81\%, respectively, for DCON and DPRO), whereas the percentage of fibers greater than $30 \mu \mathrm{m}$ increased (65.52 and $67.19 \%$ for DCON and DPRO, respectively).

Genetics and Molecular Research 16 (1): gmr16019404 
Table 3. Diameter of muscle fibers (DM) of the Nile tilapia fed diets with propolis (DPRO) and control (DCON) at $0,35,70$, and 105 days of assessment.

\begin{tabular}{|c|c|c|c|c|c|c|c|c|}
\hline \multirow[t]{3}{*}{$\mathrm{DM}(\mu \mathrm{m})$} & \multicolumn{8}{|c|}{ Assessment time } \\
\hline & \multicolumn{2}{|c|}{0} & \multicolumn{2}{|c|}{35} & \multicolumn{2}{|c|}{70} & \multicolumn{2}{|c|}{105} \\
\hline & DCON & DPRO & DCON & DPRO & DCON & DPRO & DCON & DPRO \\
\hline$<20$ & 4.73 & 5.0 & 8.73 & 12.90 & 5.50 & 8.53 & 1.84 & 2.10 \\
\hline $20-30$ & 39.49 & 40.91 & 45.98 & 45.90 & 54.43 & 66.07 & 32.63 & 30.71 \\
\hline $30-50$ & 54.96 & 52.88 & 45.21 & 40.80 & 39.72 & 25.05 & 64.47 & 65.88 \\
\hline$>50$ & 0.82 & 1.21 & 0.09 & 0.4 & 0.35 & 0.34 & $\begin{array}{c}04.47 \\
1.05\end{array}$ & $\begin{array}{c}0.00 \\
1.31\end{array}$ \\
\hline
\end{tabular}

0
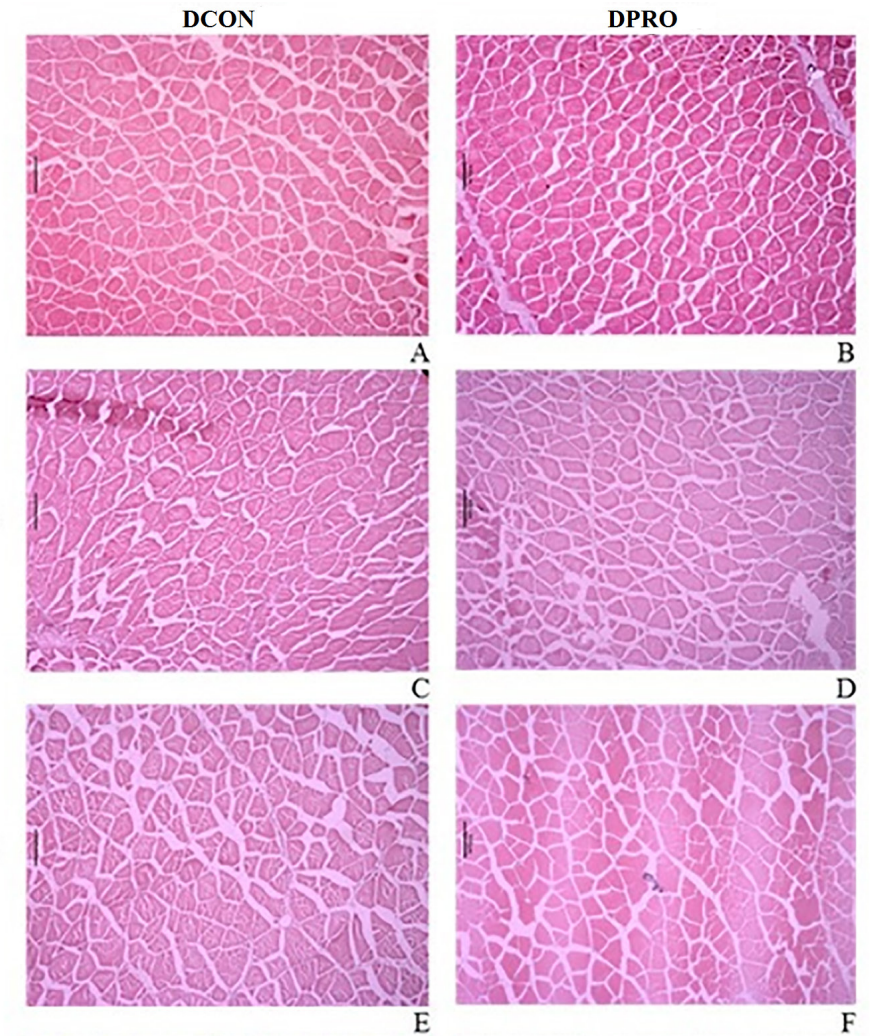

70
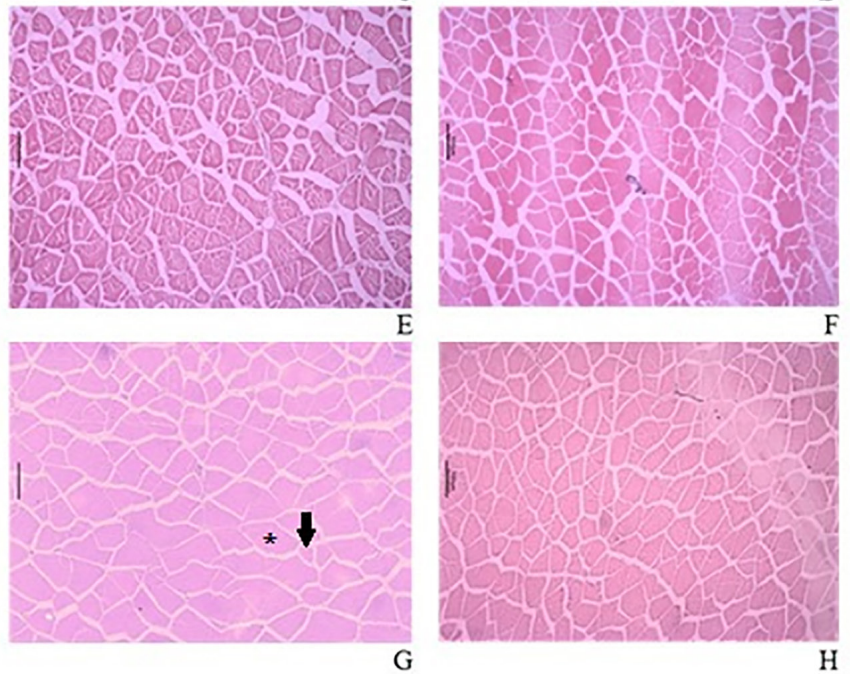

Figure 1. Photomicrography of muscle tissue of Nile tilapia (HE stain; bar $100 \mu \mathrm{m}$ ) from the control group (DCON) and the propolis treatment group (DPRO) at 0 (A and $\mathbf{B}), 35(\mathbf{C}$ and $\mathbf{D}), 70(\mathbf{E}$ and $\mathbf{F})$, and 105 days $(\mathbf{G}$ and $\mathbf{H})$. Arrow shows muscle fibers with diameter $>20 \mu \mathrm{m}$; asterisk indicates fibers with diameter $<50 \mu \mathrm{m}$. 


\section{Myostatin gene expression}

There was no statistical difference $(\mathrm{P}>0.05)$ between DPRO and DCON for myostatin levels. The results showed that genic expression of myostatin occurred at 0,35 , and 105 days, with highest gene expression at 105 days, averaging 1.93 (DCON) and 1.89 (DPRO) (Figure 2). There were increasing gene expression rates in the DPRO group and decreasing and increasing gene expression rates at 35 and 105 days, respectively, in DCON. As a rule, myostatin expression followed an increase in muscle fiber diameter throughout the breeding period.

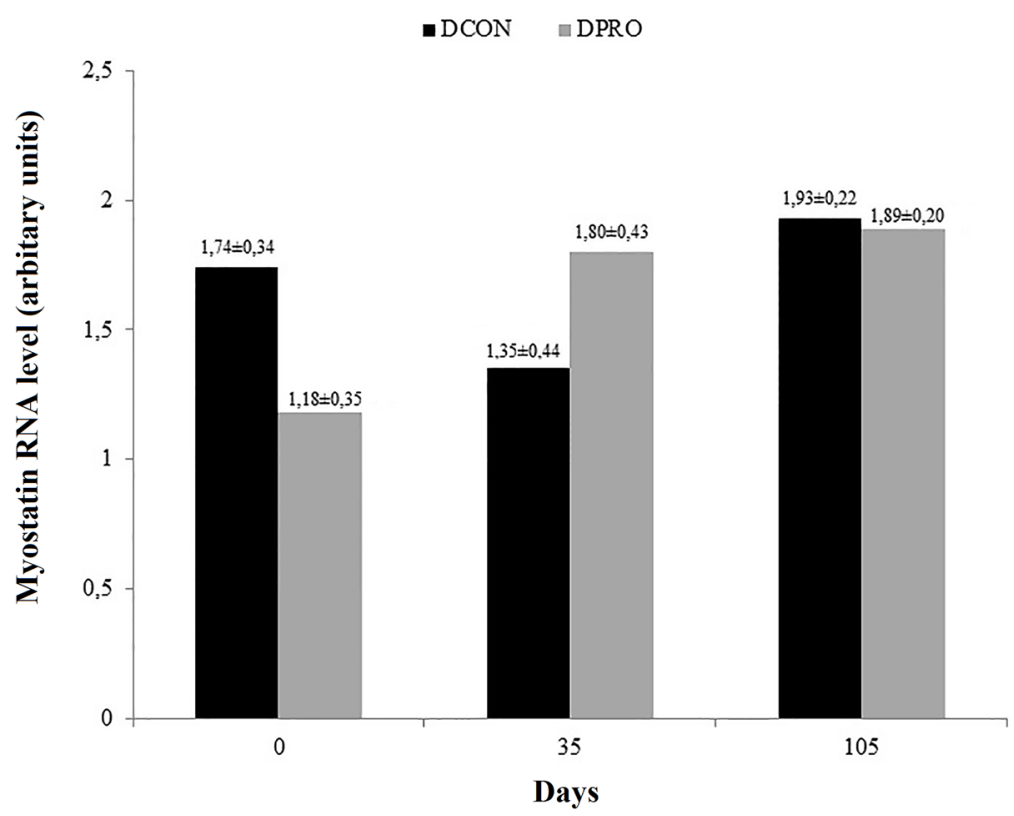

Figure 2. Relative quantification of myostatin in fish fed diets with ethanol extract of propolis (DPRO) and control fish without propolis (DCON), at 0,35, and 105 assessment days.

\section{DISCUSSION}

The cell structure of fish muscle tissue varies according to its growth phase. Smalldiameter fibers have been reported in the initial growth phases, and they correspond to greater cell proliferation. Proliferation ceases as the animal grows and muscle fibers gain volume. In other words, a greater number of muscle fibers with greater diameters may be observed in adult animals as compared to juveniles (Dal Pai-Silva et al., 2003).

Several studies have detected the same trend in the growth of white muscle fibers throughout the fish breeding period. Aguiar et al. (2008) reported greater percentages of fibers of less than $32 \mathrm{~mm}$ diameter in fries and juvenile Nile tilapia and a greater percentage of fibers of greater diameter $(>32 \mathrm{~mm})$ in adults. The distribution of muscle fiber diameter in Piaractus mesopotamicus (pacu) varied according to the animal's growth phase. In fact, fibers of $<20$ $\mathrm{mm}$ and 20-50 $\mathrm{mm}$ diameter were more frequent in juveniles, whereas diameters greater than 
$50 \mathrm{~mm}$ were more frequent in adults (de Almeida et al., 2008). Similar results were found in the current study, with a gradual decrease of fibers with smaller diameters $(<20 \mathrm{~mm})$ and an increase of fibers with diameters $>50 \mathrm{~mm}$, or rather, a decrease in the recruitment of new muscle fibers and muscle growth (process of hypertrophy) throughout the cultivation period.

Although no statistical difference $(\mathrm{P}>0.05)$ was detected between DCON and DPRO, except for days 0 and 35 in DCON, myostatin increased during the periods evaluated. According to McGivney et al. (2012) and Tripathi et al. (2013), the muscle growth process unites hyperplasia and hypertrophy, and is regulated by myogenic factors. Myostatin is a member of the genes of the transforming growth factor beta (TGF- $\beta$ ). In vitro studies on cell muscles show that myostatin inhibits myoblast proliferation and differentiation. Other studies have demonstrated that this factor might be related to the activation of differentiation and myosatellite cell fusion in fish (de Santis et al., 2012), increasing the fibers' diameter by absorbing the growing ones. Such a mechanism is linked to a negative control, which myostatin provides on the myogenic regulating factors (MRFs), whose function is the enhancement of muscle growth through the formation of new muscle fibers (Johansen and Overturf, 2005).

Increase of myostatin over time is corroborated by other studies involving myostatin paralog MSTN 1. Mareco (2012) analyzed the effect of temperature on the muscle gene of Nile tilapia (GIFT) at different periods (7, 30, and 60 days), and found lower myostatin expression on day 7 as compared to that on days 30 and 60 . The same author did not report any significant difference when the influence of temperature in the factor's gene expression was assessed. Gutierrez de Paula et al. (2014) also registered a higher expression of the gene in P. mesopotamicus at 60 days of culture at 28 and $32^{\circ} \mathrm{C}$. However, under these conditions, higher myostatin expression was reported in animals at $24^{\circ} \mathrm{C}$. Although water temperature in the current analysis was not constant since the study was performed under field conditions and not under laboratory control (a novel factor in this study), mean temperature range remained within the comfort zone for the Nile tilapia throughout most of the experiment (except mornings in November) and did not affect the gene expression analysis.

When the results of muscle morphometry and myostatin gene expression are associated, the development of the white muscle in the Nile tilapia may be presumed to be related to a greater occurrence of hypertrophied muscle fibers and to myostatin increase throughout the life cycle of the fish. There was a greater recruitment of muscle fiber $<30 \mathrm{~mm}$ (hyperplasia process) in the initial culture phases, coupled with a decrease at 105 days with a myostatin peak. When the inhibition of expression and activity of growth factors in muscle differentiation such as $M y o D$ and myogeny by myostatin (Ruan et al., 2016) are taken into account, it may be supposed that these factors were suppressed throughout the experimental period at the same time as myostatin expression, causing a recruitment decrease of new fibers and a hypertrophic increase of muscle mass in the final phases of culture.

High myostatin rates in animals fed DCON at $0 \mathrm{~d}$ and their decrease at $35 \mathrm{~d}$ (despite the increasing trend in DPRO) may be accounted for by other factors. According to Gabillard et al. (2013), myostatin is not merely related to muscle development. Its regulating mechanism involves other fish organs and tissues. Several studies have shown that diet may affect the gene MSTN 1. In their study on Oncorhynchus mykiss (rainbow trout) with low (10\%) and high (25\%) lipid levels, Galt et al. (2014) reported a significant decrease in gene expression in animals fed at high lipid rates. The authors underscored a possible relationship between lipid deposition and energy partition with a decrease in myostatin. Lates calcarifer (sea bass) submitted to a feed fast had an approximate three-fold increase in myostatin gene expression as 
compared to the control. This factor may participate in the control of apoptosis of muscle cells (De Santis and Jerry et al., 2011). Further, the concentration of fatty acids, diacylglycerols, and ceramides may induce apoptosis and decrease proliferation and differentiation of myoblasts due to the influence of myostatin (Ruan et al., 2016). Consequently, further studies are required to elucidate myostatin's inhibition mechanism. In fact, a parallel evaluation of $M y o D$ and myogenin and their activities on other tissues may elucidate more clearly the role of myostatin throughout the animal's growth phases.

Since the current experiment comprised a field assay (with net cages), several factors that affect muscle growth, such as temperature, dissolved oxygen, $\mathrm{pH}$, water flow, and the parasite and microbial loads of the fish, could not be controlled or were difficult to control. For the same reason, the current study paves the way for further research, because this type of experiment gives results that are more applicable to fish production under fish farming conditions. Analysis with greater concentrations of propolis may provide more conclusive results, since an increase in the active principals of feed facilitates their effects on muscle development. Furthermore, studies that associate propolis with other natural products, such as the alga Schizochytrium sp. (with its great capacity for tilapia growth), may provide more relevant results with regard to the genes that control muscle growth. Studies on fish species other than tilapia with different fat/muscle percentages, such as Colossoma macropomum and Piaractus mesopotamicus, may provide different results from those of the current investigation. They may also be of great importance in understanding muscle growth regulation in these species.

Results of this novel trial showed that propolis affected neither muscle development nor myostatin in Nile tilapia bred in net cages. Owing to the large number of chemical compounds in propolis, such as ketones, amino acids, several types of alcohol, polysaccharides, fatty acids, and others (Marcucci, 1996), and to its positive effects on animal production, more analyses should be undertaken. Research coupling sustainability and productivity is highly relevant for the productive chain in fish farming. The understanding of muscle growth and development processes and the way that feed supplements affect these processes are important for the incorporation of knowledge and technology. Further investigations are needed to verify the hypothesis that propolis, a growth enhancer, affects the inhibition of regulation factors of tilapia muscle genes.

\section{Conflicts of interest}

The authors declare no conflict of interest.

\section{ACKNOWLEDGMENTS}

The authors would like to thank Fundação Araucária for funding this study.

\section{REFERENCES}

Abd-El-Rhman AMM (2009). Antagonism of Aeromonas hydrophila by propolis and its effect on the performance of Nile tilapia, Oreochromis niloticus. Fish Shellfish Immunol. 27: 454-459. http://dx.doi.org/10.1016/j.fsi.2009.06.015

Adamante WB, Nuñer APO, Barcellos LJG, Soso AB, et al. (2008). Stress in Salminus brasiliensis fingerlings due to different densities and times of transportation. Arq. Bras. Med. Vet. Zootec. 60: 755-761. http://dx.doi.org/10.1590/ $\underline{\text { S0102-09352008000300034 }}$

Genetics and Molecular Research 16 (1): gmr16019404 
Aguiar DH, Bock C, Padovani CR and Pai-Silva MD (2008). MyoD, myogenin and proliferating cell nuclear antigen expression in growing Nile tilapia (Oreochromis niloticus L.). Aquacult. Res. 39: 1673-1679.

Bankova V (2005). Recent trends and important developments in propolis research. Evidence-based Complement. Altern. Med. 2: 29-32.

Bae JY, Park GH, Lee JY, Okorie OE, et al. (2012). Effects of dietary propolis supplementation on growth performance, immune responses, disease resistance and body composition of juvenile eel, Anguilla japonica. Aquacult. Int. 20: 513-523. http://dx.doi.org/10.1007/s10499-011-9482-4

Castagnolli N (1992). Piscicultura de água doce. Funep, Jaboticabal.

Dal Pai-Silva M, Carvalho RF, Pellizzon CH and Dal Pai V (2003). Muscle fibre types in tilapia do Nilo (Oreochromis niloticus) from larval to adult: histochemical, ultrastructural and morphometric study. Tissue Cell 35: 179-187. http:// dx.doi.org/10.1016/S0040-8166(03)00019-3

de Almeida FL, Carvalho RF, Pinhal D, Padovani CR, et al. (2008). Differential expression of myogenic regulatory factor MyoD in pacu skeletal muscle (Piaractus mesopotamicus Holmberg 1887: Serrasalminae, Characidae, Teleostei) during juvenile and adult growth phases. Micron 39: 1306-1311. http://dx.doi.org/10.1016/j.micron.2008.02.011

De Santis C and Jerry DR (2011). Differential tissue-regulation of myostatin genes in the teleost fish Lates calcarifer in response to fasting. Evidence for functional differentiation. Mol. Cell. Endocrinol. 335: 158-165. http://dx.doi. org/10.1016/j.mce.2011.01.011

Deng J, An Q, Bi B, Wang Q, et al. (2011). Effect of ethanolic extract of propolis on growth performance and plasma biochemical parameters of rainbow trout (Oncorhynchus mykiss). Fish Physiol. Biochem. 37: 959-967. http://dx.doi. org/10.1007/s10695-011-9493-0

Franco SL and Bueno JHF (1999). Otimização de processo extrativo de própolis. Infarma 11: 48-51.

Fuller R (1992). History and development of probiotics. In: Probiotics: the scientific basis (Fuller R). Chapman \& Hall, London, 1-18.

Gabillard JC, Biga PR, Rescan PY and Seiliez I (2013). Revisiting the paradigm of myostatin in vertebrates: insights from fishes. Gen. Comp. Endocrinol. 194: 45-54. http://dx.doi.org/10.1016/j.ygcen.2013.08.012

Galt NJ, Froehlich JM, Meyer BM, Barrows FT, et al. (2014). High-fat diet reduces local myostatin-1 paralog expression and alters skeletal muscle lipid content in rainbow trout, Oncorhynchus mykiss. Fish Physiol. Biochem. 40: 875-886. http://dx.doi.org/10.1007/s10695-013-9893-4

Ibge (2014). Produção da pecuária municipal. Available at: [http://biblioteca.ibge.gov.br/visualizacao/periodicos/84/ ppm_2014_v42_br.pdf]. Accessed 11 March 2016.

Johansen KA and Overturf K (2005). Quantitative expression analysis of genes affecting muscle growth during development of rainbow trout (Oncorhynchus mykiss). Mar. Biotechnol. (NY) 7: 576-587. http://dx.doi.org/10.1007/ $\underline{\text { s10126-004-5133-3 }}$

Kubitza F (2011). Tilápia: tecnologia e planejamento na produção comercial. 2nd ed. Aqua Supre, Jundiaí.

Lara-Flores M, Overa-Novoa M and Guzmán-Mendez BE (2003). Use of bacteria Streptococcus faescium and Lactobacillus acidophilus, and the yeast Saccharomyces cerevisiae as growth promoters in Nile tilapia (Oreochromis niloticus). Aquaculture 216: 193-201. http://dx.doi.org/10.1016/S0044-8486(02)00277-6

Marcucci MC (1996). Propriedades biológicas e terapêuticas dos constituintes químicos da própolis. Quim. Nova 19: 529.

Mareco EA (2012). Efeitos da temperatura na expressão de genes relacionados ao crescimento muscular em tilápias do Nilo (Oreochromis niloticus) linhagem GIFT. Master's Thesis, UNESP, Botucatu.

McGivney BA, Browne JA, Fonseca RG, Katz LM, et al. (2012). MSTN genotypes in Thoroughbred horses influence skeletal muscle gene expression and racetrack performance. Anim. Genet. 43: 810-812. http://dx.doi.org/10.1111/ j.1365-2052.2012.02329.x

Meurer F, Costa MM, Barros DAD, Oliveira STL, et al. (2009). Brown propolis extract in feed as a growth promoter of Nile tilapia (Oreochromis niloticus, Linnaeus 1758) fingerlings. Aquacult. Res. 40: 603-608. http://dx.doi. org/10.1111/j.1365-2109.2008.02139.x

Nayak SK (2010). Probiotics and immunity: a fish perspective. Fish Shellfish Immunol. 29: 2-14. http://dx.doi. org/10.1016/j.fsi.2010.02.017

Gutierrez de Paula T, de Almeida FL, Carani FR, Vechetti-Júnior IJ, et al. (2014). Rearing temperature induces changes in muscle growth and gene expression in juvenile pacu (Piaractus mesopotamicus). Comp. Biochem. Physiol. B Biochem. Mol. Biol. 169: 31-37. http://dx.doi.org/10.1016/j.cbpb.2013.12.004

Pfaffl MW (2001). A new mathematical model for relative quantification in real-time RT-PCR. Nucleic Acids Res. 29: e45. http://dx.doi.org/10.1093/nar/29.9.e45

Rasmussen R (2001). Quantification on the lightcycler. In: Rapid cycle real time PCR: methods and applications (Meuer S, Witter C and Nakagawara K, eds.). Spring, Berlin, 21-34.

Genetics and Molecular Research 16 (1): gmr16019404 
Ruan J, Zhang Y, Yuan J, Xin L, et al. (2016). A long-term high-fat, high-sucrose diet in Bama minipigs promotes lipid deposition and amyotrophy by up-regulating the myostatin pathway. Mol. Cell. Endocrinol. 425: 123-132. http:// dx.doi.org/10.1016/j.mce.2016.02.001

de Santis C, Gomes GB and Jerry DR (2012). Abundance of myostatin gene transcripts and their correlation with muscle hypertrophy during the development of barramundi, Lates calcarifer. Comp. Biochem. Physiol. B Biochem. Mol. Biol. 163: 101-107. http://dx.doi.org/10.1016/j.cbpb.2012.05.008

Segvic-Bubic T, Boban J, Grubisic L, Trumbic Z, et al. (2013). Effects of propolis enriched diet on growth performance and plasma biochemical parameters of juvenile European sea bass (Dicentrarchus labrax L.) under acute lowtemperature stress. Aquacult. Nutr. 19: 877-885. http://dx.doi.org/10.1111/anu.12032

Tripathi AK, Ramani UV, Patel AK, Rank DN, et al. (2013). Short hairpin RNA-induced myostatin gene silencing in caprine myoblast cells in vitro. Appl. Biochem. Biotechnol. 169: 688-694. http://dx.doi.org/10.1007/s12010-012$\underline{0021-1}$

Uczay J, Pianesso D, Adorian TJ, Mombach PI, et al. (2014). Própolis em dietas para o jundiá (Teleostei, Pimelodidae). Biosci. J. 30: 1912-1918.

Genetics and Molecular Research 16 (1): gmr16019404 